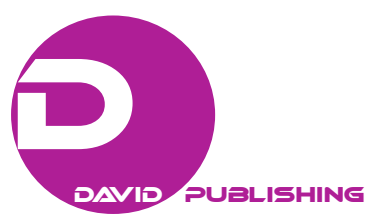

\title{
The Importance of Being Poirot: A Critical Examination of "Curtain" as Seen on ITV
}

\author{
Serena Formica \\ The University of Derby, Leeds, UK
}

\begin{abstract}
Hercule Poirot has died, and his death was witnessed by the nearly five million viewers of "Curtain: Poirot's last case", the concluding episode of the long lasting ITV television series Agatha Christie's Poirot. Poirot was played for one final time by David Suchet, who, in the course of the series, has managed to appropriate the character to an extent that no previous actor has achieved. This article suggests that Suchet has indeed made of Poirot a "fictional celebrity", and analyses "Curtain" on the one hand by looking at its critical reception, and on the other by considering the hour-long documentary Being Poirot, in which David Suchet discusses his personal journey as the character.
\end{abstract}

Keywords: Agatha Christie, Poirot, David Suchet

Wednesday the 13th of November 2013 marked a significant date for several UK viewers: Hercule Poirot passed away. Thirty eight years after Poirot's death on paper in 1975 the Belgian detective died on the small screen, in "Curtain: Poirot's Last Case", the last episode of Agatha Christie's Poirot. It is estimated that almost five million viewers (Jeffery, 2013) witnessed the death of the Belgian detective, played in a "subdued but stunning form" (Frost, 2013) by David Suchet.

David Suchet is one of a significant number of actors who have impersonated the character of Hercule Poirot, from Peter Ustinov to Albert Finney, not to mention Alfred Molina and Tony Randall. However, none of them have received the same level of recognition, or have they had the same endorsement by the Agatha Christie's trust. Ennis (1986, p. 4) mentions to Christie's objections to Charles Laughton, Austin Trevor and Francis L. Sullivan, reporting that Christie was reasonably happy with Albert Finney's interpretation, with the exception of his moustaches, but was annoyed by Charles Laughton stage impersonation of her character (Haining, 1995, p. 4).

In this article the author will look at the final act of Poirot's career, as adapted for the hugely popular ITV series Agatha Christie's Poirot, on the one hand by examining its critical reception, and on the other hand by considering the hour-long documentary Being Poirot, introduced by the actor and aired within an hour of Curtain's rolling credits.

The first episode of Agatha Christie's Poirot, "The Adventure of the Clapham Cook", based on the 1924 short story, was broadcast on ITV in 1989. Initially only short stories were adapted for the small screen, because they could more easily be turned into the hour-long format. In "The Adventure of the Clapham Cook", Poirot was introduced to the audience as a well-established detective, who already had a strong working

Serena Formica, Ph.D., College of Law, Humanities and Social Sciences, The University of Derby. 
partnership with Captain Hastings. This first episode was adapted from a short story published in the UK on The Sketch in November 1923 (Christie, 1923). As a book form, this short story appeared in the US before than in the UK. In fact, it was published in America as part of The Under Dog and Other Stories (Christie, 1951), and it was not until 1974 that "The Adventure of the Clapham Cook" appeared in UK in the collection Poirot's Early Cases (Christie, 1974). In September 1990, on the occasion of the centenary of Agatha Christie's birth, ITV broadcast the first feature-length film, "The Mysterious Affair at Styles" adapted from the eponymous novel in which Poirot makes his first appearance.

David Suchet's interpretation of Poirot has received praises not only from critics and audiences, but also by the Agatha Christie's Estate. Matthew Prichard, Agatha Christie's grandson and main heir, said

...personally, I regret very much that she never saw David Suchet. I think that visually he is much the most convincing. [O]ver the .... years we have come closer, thanks to LWT ... to a visual realization of one of the great detective creations of the century. (Haining, 1995, p. 7)

The film is the latest production of the long-lasting TV series, which started in 1989 with the approval of the Estate. Producer Brian Eastman had worked with David Suchet in the BBC series Blot on the Landscape, 1986, in which the actor played a handyman wearing a beret and small moustache. In viewing the series, Agatha Christie's daughter Rosalind Hicks suggested that Suchet would make "a wonderful Poirot" (Haining, 1995, p. 11).

The author argues that Suchet is the only actor who has managed to become the fictional character whom he has impersonated for so many years. This has not happened, for example, in the case of Miss Marple. Critics and the public agree in considering Joan Hickson the definite Miss Marple. The actress played the character in the BBC television series Agatha Christie's Miss Marple (1984-1992), but unlike Suchet, she has not been Marple in a series, which included every single adaptation of the stories featuring the amateur detective. The other actresses who have impersonated the character include Geraldine McEwan Julia McKenzie. A separate mention has to be made of Margaret Rutherford, whose impersonation of Miss Marple is quite unrealistic and gives the character an edge, which is borderline between funny and ridiculous. A character that more than one actor have made their own is James Bond, but can Poirot be considered on the same level as Bond in terms of popularity?

Wollacott and Bennet (1987) argued that Poirot could not be considered a popular hero on the same level.

Hercule Poirot..., for example, ha[s] no significantly developed existence other than as character in the novels of Agatha Christie ... and the films and television adaptations based on them; one needs either to have read ... these to know who these characters are and the cultural values they stand for. Whereas popular heroes also usually have their origins in a particular work or body of fiction, they break free from the originated textual conditions of their existence to achieve a semi-independent existence, functioning as an established point of cultural reference that is capable of working ... even for those who are not directly familiar with the original texts. (p. 14)

David Suchet started impersonating Poirot two years after these words were written, and he has arguably managed to inscribe Poirot into the category of popular hero, or as the author prefer to call it, fictional celebrity. (Haining, 1995, p. 4). Suchet has managed to become Poirot for multiple reasons. Firstly, he is the only actor who has achieved playing a fictional character in the adaptation of every single story ever written about that character. Secondly, the author — admittedly anecdotal — experience suggests that when mentioning to a British audience the name of "Poirot", Suchet's is the immediate mental association that comes to mind. Thirdly, Suchet's has been hailed by the Christie's Estate as the ultimate Poirot. 
"Curtain's" broadcast was followed by Being Poirot, a-behind-the-scenes documentary on the ITV series, presented by David Suchet. In the documentary, the actor visits Belgium, the birthplace of Hercule Poirot. In Brussels' Gallery, he meets Sten Lauryssens, a Belgian crime writer, to investigate the importance of the character for the locals. It is worth to report part of their conversation:

Suchet: Do you think that Poirot is typically Belgian?

Lauryssens: he is typically Belgian because he's got all the mannerism of Belgians, no? First of all, they are short. They are good looking...

Suchet: Oh, that's very kind. (Malone, 2013) ${ }^{1}$

Interestingly, in this passage, Suchet thinks of himself as Poirot. Suchet is not Belgian, yet, when Lauryssens refers to Belgians as good looking, Suchet thanks him. What is happening here is a transfer of personas: The fictional persona of Poirot is being transferred to the real persona of Suchet to an extent that they merge into one. The conversation between the actor and the author continues with Suchet asking:

Suchet: What makes Poirot so endearing?

Lauryssens: His warmth. You cannot be mad at him.

Poirot: you are speaking of Poirot as though [he] was a real person.

Lauryssens: he is.

Suchet: he is?

Lauryssens: Who says he's fictional. Every night, at home, anywhere in the world, there you are. You made him a living person. And that's your fault. (Malone, 2013)

The extent to which Suchet sees himself has Poirot is made clear earlier in the documentary, when the actor visits the local museum of Torquay, Christie's birthplace. Suchet presents Carl Smith and Amie Schofield - the museum's curators - with Poirot's famous walking stick. Suchet is then shown around the museum, where a newly refurbished area is entirely dedicated to Christie, in which Poirot's living room has been recreated. "Look! [It] is my flat!" exclaims Suchet. Then he becomes aware of his words: "My flat? Poirot's flat", yet, he continues indicating the desk as "my desk", and the radio, as "my radio". "I know that this is in the public domain now, 'continues the actor' 'and yet I feel so possessive about it all! ... It's got nothing to do with me!" (Malone, 2013). Or has it? As Sten Lauryness put it, "That is your fault". In this very brief statement is the key to understanding what Suchet, has done to Poirot for millions of viewers and readers worldwide: He has made him real. Through 25 years on television Suchet has transformed Poirot from a fictional character to a real character, from a fictional celebrity to a real celebrity, enabling Poirot to assume a dimension that transcends both the page and the screen, encompassing other media platforms. On the small screen, Suchet appears simultaneously in body and voice; the two are separated in Suchet's other appearances as Poirot: in Agatha Christie audiobooks, Suchet becomes the omniscient narrator as well as reprising is disembodied role as the Belgian detective. In the video game "Agatha Christie. Murder on the Orient Express" (Adventure Company, 2006) ${ }^{2}$. Suchet lends his physical appearance and voice acts the avatar of Poirot. In the Japanese anime No Metaintei Poirot to Marple, the character of Poirot assumes a semblance which arguably echoes the physical build and facial traits of David Suchet.

Becoming Poirot to the extent that Suchet has achieved is a rather more difficult task that it may at first appear. Through the history of acting many actors have successfully played existing people, recent examples

\footnotetext{
${ }^{1}$ Malone, C. (Director). (2013). Being Poirot [Television Broadcast]. London, UK: ITV.

2 Adventure Company. (2006). Agatha Christie. Murder on the Orient Express. [Video Game]. London and New York: Chorion.
} 
being Eddie Redmayne's impersonation of Stephen Hawking, Daniel Day Lewis as Lincoln in Steven Spielberg's 2012 film by the same title. These performances have resulted in Academy Awards and public acclamation. To prepare for the role Redmayne spent six months in the company of people with moto neuron disease, including Stephen Hawking (French, 2014), and had to "train his body like a dancer", effectively applying method acting techniques to his approach. Similarly, Day Lewis did extensive research before playing the US president, staying in character during filming (Brooks, 2013) and reeving the plaudit of historians for his realistic representation (Singh, 2012).

Impersonations Hawking and Lincoln persons, both present different challenges: physical, mental, and, in the case of Lincoln, with the added complication that the president lived before recordings of even his voice were possible. To these difficulties, impersonating Poirot adds another: Unlike Lincoln and Hawking, Hercule Poirot never existed in flesh and blood, but only on the page. Yet, it would be wrong to assume that, since he is a fictional character, the same methods cannot be applied to obtain a satisfactory and ultimately successful result. In fact, according to critics, Suchet has employed "method acting tricks" to play the detective. In an article on The Independent, Runcie lists six ways in which "David Suchet turned himself into the ultimate Poirot; [b]e prepared; [t]he walk; [t]he moustache; [t]he paunch; ... zee accent [and] one lump or two [of sugar]" (Runcie, 2013).

Suchet, as aforementioned, has turned Poirot into a celebrity. Graeme Turner provides an interesting study into what a celebrity is, and highlights that the concept changes depending on the point of view of consideration. Celebrity is at the same time the manifestation of a "shift towards a culture that privileges the momentary", a person with "natural and magical qualities", an industry, a "product of an economic process" (Turner, 2010, p. 4). Hercule Poirot can be seen as all of those: He plays a role within popular culture; he certainly has magical qualities, as his little grey cells are able to solve the most difficult of crimes, and he is the cultural product of an economic process. Christie's success can be ascribed to her creative imagination, but also to the fact that she was able to capture an increasing need for fictional crime, and her books were published in formats that could be easily read on a train during a commute. Poirot's celebrity status transcends the paper on which he was born, and extends to theatre, cinema, computer games, Japanese animation and the small screen.

In November 2013, Suchet made his last appearance as Poirot in "Curtain". The episode has a sombre atmosphere from the outset; it opens in a courtroom, as a judge reads out a verdict, on the opening notes of Chopin's "Raindrop Prelude" (Op. 28 No. 15); a woman is seen weeping, as the defendant in the trial is found guilty and hanged. The same woman plays the piano as the music becomes diegetic, a close up briefly shows a pair of patent leather shoes, and a hand plighted with arthritis. A long over the shoulder shot reveals a man sitting on a wheelchair, intent to listening: As the camera pans around, we finally see a much aged Poirot.

In the opening scenes, we learn that other than arthritis, Poirot suffers from angina, a debilitating heart condition that ultimately causes his death. However, his illness does not stop Poirot from wanting to find out the truth about a series of suspicious deaths. He knows that a murderer is at Styles, and strongly suspects that a murder will take place in the mansion.

The identity of the killer is unknown, and so is the identity of the victim. Soon however, Poirot has his first suspicions, but he does not reveal his thoughts to Hastings, not to compromise his detection work. Should the Captain know the truth, his judgment would be compromised, and so will his relationship with people. In the absence of snooping Poirot, "Curtain" presents the viewer with a reluctantly snooping Hastings, who has more than just a murder investigation on his mind. He has, in fact, recently become a widower, and, at Styles, is reunited with his daughter Judith, who is the assistant of Doctor Franklin, a tropical biologist. 
In "Curtain", Christie offers one last murder mystery, with all the staples of classic Poirot novels. The action takes place in an enclosed location, with a restricted number of characters who all know each other. This last case, however, also presents some diversions. Generally, Christie's novels are typical whodunits: A murder is committed, and the detective, with the help of his associate, has to find the culprit. Each of the characters has a reason for wanting the death of the victim, and each is in turn suspect. With the gathering of clues the number of suspects reduces until the final dénouement, where Poirot gathers the suspects in one room, and reconstructing the events, reveals the murderer.

The clues collected are often unlikely pieces of evidence, such as the changed position of objects on a mantelpiece, and often it is the subtle psychological changes that present Poirot with the solution to a mystery. In "Curtain", there is no immediate victim, and Poirot must prevent a murder from taking place, rather than being immediately presented with a crime. The clues to the identity of the killer must be obtained from previous cases in which either a death has occurred and has been shelved as an accident or a suicide, or in which the murderer has already been convicted and hanged. Poirot harbours doubts in each of the cases, and suspects that a single, shrewd, and dangerous mind is behind all of those death. The Belgian detective is on the traces of a cunning assassin, who poisons the minds of weak people in order to persuade them to commit the ultimate crime: murder.

Hastings soon becomes an obvious target: He is blinded by jealousy over Judith's latest flame, Major Allerton, and prepares to kill him with poison. Fortunately, Poirot is able to read his friend's mind thus preventing Hasting's foolish act. Heart illness and arthritis, in fact, have restricted Poirot's movement but have not clouded his mind. Alas, the sleuth is not able to prevent the murderer, unassuming Mr Norton, from causing another death. Mr Norton, who feels unloved and unappreciated, cunningly persuades Mrs Franklin in killing her husband, but an accidental swap of the poisoned cup means that she kills herself instead. By this point, Poirot knows that he is running out of time: The moment of his own death is approaching, and Norton must be stopped.

Norton's body is found one morning with a bullet in the centre of his forehead, and the inquest passes a verdict of suicide. Shortly afterwards, Poirot is found dead in his bedroom, where he suffered one last fatal heart attack. Four months after his death, Hastings receives a letter, in which Poirot reveals the truth. Knowing that Norton could not be stopped by a court of law, Poirot, who had concealed to everyone that he was still able to walk, had first drugged Norton and then killed him. The symmetric nature of his head wound should have revealed the truth to Hastings.

According to the BBC figures, the programme was watched by the $23 \%$ of the total number of viewers and received almost unanimous positive reviews. The Daily Telegraph praises the fact that the episode did not "bow[ed] out in a burst of self-congratulatory glory" (Walton, 2013). The review underlines that "While its main character has happily blown away on his own trumpet, the show itself has always gone about its business with a quiet, bravely unhurried and wholly effective commitment to Christie's story-telling" (Walton, 2013).

"Curtain"'s tone, is indeed, in line with the latest seasons of Agatha Christie's Poirot. Since the 2010 episode "Murder on the Orient Express", in fact, Poirot has undergone a transition from a young(er) and jovial investigator to a grave and wise detective. The series has gradually become darker, more introspective, and a cynical and far more religious side of Poirot has emerged. In "Murder on the Orient Express" (Christie, Harcourt, $\&$ Martin, 2010), Poirot, who is a strong catholic, throws away his rosary after having made the difficult decision not to hand over to the police the people responsible for killing Mr Rachett. In "Curtain", Poirot is seen praying 
incessantly, asking God to help him to make the right choice: allowing a murderer to commit more crimes or stopping him by committing the ultimate crime? Eventually Poirot becomes the jury, the judge and the unlikely executioner.

A few days later, Poirot has one last conversation with Hastings. The camera remains with the sleuth, bedridden and with serious chest pain. Hastings descends the stairs; Poirot's arm, in the foreground, reaches for his medicine on the bedside table. A close up focusses on the rosary lying next to the sniffing medicine. After a slight hesitation, Poirot, breathing heavily, reaches for the rosary. The camera almost imperceptibly zooms in on Poirot's face, while he whispers, "forgive me". A melancholic piano music reprises the opening tune and as Hasting enters the drawing room he notices Elizabeth Coleat the instrument. The Captain suddenly stops, while the realisation of Poirot's death dawns on him. The woman stops playing as Hasting runs out of the room, at the sound frantic orchestral music that has become non-diegetic. Hastings, in slow motion, enters the room, and we read on his face all that we need to know: Poirot is no more.

Director Hettie MacDonald handles Poirot's death with great dignity, allowing the audience to be at the detective bedside until almost the very last, but does not allow the viewer to witness moment in which he actually passes away. The last image that we have of Poirot, however, is a rather more pleasing one: The detective is seated at his desk, and has just finished writing his letter to Hastings. At this point Poirot, breaking the fourth wall, looks directly at the camera, smiling, while a voice over exclaim: "Ah Hasting, my dear friend, they were good days, ah yes, they have been good days" (MacDonald, 2013). It is unquestionable that ITV and David Suchet have given its viewers twenty four good years indeed.

\section{References}

Bamford, R. \& Sharp, T. (Writers), \& Bradbury, M. (Director). (1985). Blot on the Landscape. [Television broadcast]. In B. Eastman (Producer), London, UK: BBC.

Brooks, X. (2013). Lincoln secures Daniel Day-Lewis a record third best actor Oscar. Retrieved March 9, 2015, from http://www.theguardian.com/film/2013/feb/25/oscars-2013-daniel-day-lewis-lincoln-actor

Christie, A. (1923). The adventure of the Clapham Cook. Daily Sketch Magazine.

Christie, A. (1951). The under dog and other short stories. New York: Dodd, Mead and Company.

Christie, A. (1974). Poirot's early cases. London: Collins.

Christie, A., Elyot, K., \& MacDonald, H. (Director). (2013). Curtain: Poirot'slast case. [Television series episode]. In D. Boulter (Producer), Agatha Christie's Poirot. London, UK: ITV.

Christie, A., Harcourt, S. (Writers), \& Martin, P. (Director) (2010). Murder on the Orient Express. [Television broadcast]. In K. Thrussell (Producers). London, UK: ITV.

Christie, A., Harcourt, S. (Writers), \& Martin, P. (Director). (2010). Murder on the Orient Express. [Television broadcast]. In K. Thrussell (Producers), London, UK: ITV.

Curran, J. (2010). Agatha Christie's secret notebooks: Fifty years of mysteries in the making. London: Harper Collins.

Eames, T. (2013). Poirot concludes with 4.9 million viewers on ITV: Digital spy. Retrieved from http://www.digitalspy.co.uk/displayarticle.php?id=531194

Ennis, J. (1986). It's back to the drawing room for a perfect Poirot. TV Times, 4-5.

Exton, C., Christie, A. (Writers), \& Bennett, E. (Director). (1989). The adventure of the Clapham Cook. [Television series episode]. Agatha Christie's Poirot. London, UK: ITV.

French, L. (2014). Genius performance: Eddie Redmayne on playing Stephen Hawking. Retrieved March 9, 2015, from http://www.biography.com/news/theory-of-everything-eddie-redmayne-interview

Frost, C. (2013). Curtain: Poirot's final case: Review finds David Suchet in subdued but stunning form as Belgian detective signs off.

Retrieved

from

http://www.huffingtonpost.co.uk/2013/11/13/poirot-review-curtain-final-case-david-suchet_n_4269653.html

Haning, P. (1995). Agatha Christie's Poirot: A celebration of the great detective. London: Boxtree/LWT. 
Jeffery, M. (2013). David Suchet on Poirot's finale: It was the hardest shoot of my life. Retrieved from http://www.digitalspy.co.uk/displayarticle.php?id=529835

Kellaway, K. (2014). Eddie Redmayne: To play Hawking I had to train my body like a dancer. Retrieved March 9, 2015, from http://www.theguardian.com/film/2014/dec/07/eddie-redmayne-to-play-hawking-i-had-to-train-my-body-like-a-dancer

Runcie, C. (2013). How to play Poirot: David Suchet's method acting tricks. Retrieved from http://www.telegraph.co.uk/culture/tvandradio/10441147/How-to-play-Poirot-David-Suchets-method-acting-tricks.html

Shûkichi, K. (Producer). (2004-2005). Agasa Kurisutî no meitantei Powaro to Mâpuru [Television Series]. Tokio NHK Enterprises.

Singh, A. (2012). Daniel Day-Lewis faces criticism for giving a voice to Abraham Lincoln. Retrieved from http://www.telegraph.co.uk/culture/film/film-news/9668370/Daniel-Day-Lewis-faces-criticism-for-giving-a-voice-to-Abraha m-Lincoln.html

Turner, G. (2004). Understanding celebrity. Los Angeles and London: Sage.

Walton, J. (2013). Poirot's last case, ITV, review. Retrieved from http://www.telegraph.co.uk/culture/tvandradio/tv-and-radio-reviews/10447645/Poirots-Last-Case-ITV-review.html

Wollacott, J., \& Bennett, T. (1987). Bond and beyond: The political career of a popular hero. London: Macmillan Education. 